\title{
Livro - 21 dias: Memórias de uma Ocupação Estudantil
}

Prof. ${ }^{a}$ Dr. ${ }^{a}$ Yvone

Dias Avelino

Professora Titular do

Departamento de História da Pontifícia Universidade Católica de São Paulo .

\section{ROSSINI, Cyntia: Editora Dava Editorial/ São Paulo. 2018.}

A presente publicação de autoria da Professora Cyntia H. Rossini é resultado de uma exaustiva e competente pesquisa. Parte dela, conforme esclarece a própria autora, iniciou-se no Curso de Pós-Graduação Lato Senso, História Sociedade e Cultura, da Pontifícia Universidade Católica de São Paulo, onde foi minha aluna na disciplina Espaço Urbano.

Com a apresentação de um projeto de pesquisa para a elaboração de seu TCC, quando, nessa vertente de análise, tive o imenso prazer de conduzir suas reflexões em continuidade ao que já havia sido iniciado pela Prof. ${ }^{a}$ Me. Maria Auxiliadora Guzzo Dedecca, nossa querida Lilia, que, infelizmente, faleceu.

Competente e arrojada, Cyntia desdobrou o projeto para publicação desta importante obra de cruzamentos entre memória e História, na qual conseguiu com larga experiência me deslumbrar com a forma séria, científica e metodológica com que refletiu essas relações em diferentes áreas de estreitos laços. Essas duas áreas se entrelaçam em diversos momentos da experiência humana, como demonstra de forma prática este feliz resultado apresentado ao público leitor em geral, extramuros da universidade e da Escola Caetano de Campos.

O universo acadêmico, entre suas diversas funções, coloca-nos diante de variadas atribulações, nas quais, às vezes, resultam no acúmulo de tarefas. Esse espaço universitário, no entanto, concede-nos também momentos felizes, como este, o de construir uma resenha para uma obra de relevante interesse, não só para a Educação, ao exercício da cidadania, à historiografia contemporânea e aos sujeitos que participaram da luta de acampar durante 21 dias no espaço da Escola - luta, aliás, que valeu uma grande vitória, e também uma contribuição para os estudiosos da temática, nacional ou internacionalmente.

Não é fácil a incumbência que ora assumo, pois sempre sentimos certo receio de não correspondermos às expectativas destes, ontem nossos alunos, e hoje nossos colegas na docência - que, em muitos casos, superam os mestres, como é o caso de Cyntia -, além do risco de omitirmos também informações substanciosas a 
respeito da obra resenhada. Leitores diversos lançarão sobre ela olhares críticos diferentes desses meus, mas sempre serão objetos de crescimento para a autora.

O estudo apresentado centrou-se na análise dos processos educacionais e a proposta do Governo do estado de São Paulo na reorganização escolar, que previa que 96 escolas fossem encaminhadas para outros espaços na área da educação. A Secretaria de Educação defendia a separação de crianças e adolescentes, dividindo as unidades em ciclos: do primeiro ao quinto do Ensino Fundamental I e do sexto ao nono do Fundamental II e do Ensino Médio. Com essa atitude, as escolas concentrariam alunos da mesma faixa etária. Teoricamente, era o deslocamento de alunos de uma escola para outra, em um raio de $1,5 \mathrm{Km}$ da unidade de origem. Segundo o Secretário da Educação à época, Herman Voorwald, no cargo entre dezembro de 2010 até novembro de 2015, tratava-se "de um novo modelo de escola". A Rede Estadual Paulista contava, na ocasião, com 5.108 escolas, com 3,8 milhões de alunos. A escola reagiu. Várias pessoas reagiram. E a autora apresenta algumas observações sobre isso, embora analise com maiores detalhes a Caetano de Campos.

Apresentando as particularidades de um processo educacional e político, e mostrando as Constituições de 1824, 1891, 1934, 1937, 1946, 1967 e 1988, a inteligente historiadora dividiu o seu livro em duas importantes partes.

Dedicou a primeira parte - Brado Retumbante - a apresentar o que cuidadosamente amealhou com sujeitos que vivenciaram a história da ocupação dos estudantes e professores na Escola Estadual Caetano de Campos, na Aclimação, em 2015. Utilizando com perfeição a técnica da documentação oral, conseguiu textos/documentos preciosos que podem servir para futuras pesquisas pela clareza com que relatam um projeto absurdo que provocou um caos na escola pública.
Precedendo essa primeira parte, o livro apresenta ainda um Sumário, uma lista de colaboradores, agradecimentos, apresentação e um bom prefácio da Profa. Dra. Silvia Soler Bianchi.

Em seguida aos cuidadosos e exemplares testemunhos, o livro apresenta um encarte de fotos da memória da ocupação, para, na segunda parte do livro, Cyntia revelar, de forma substanciosa, a sua contribuição de competente historiadora: todo um processo educacional brasileiro, em que oferece uma leitura importante sobre os estudos educacionais de forma esclarecedora. Essa parte é dividida em cinco capítulos: No primeiro capítulo, Utopia da Cidade, Cidadania Utópica, no qual desenvolve conceitos de cidadania, direitos e obrigações do cidadão. No segundo capítulo, Caetano de Campos: Fundação preservação e memória, em que descreve a Escola Caetano de Campos e os seus anos de vivência nela como aluna, relacionando-os à história do Brasil nesse período e descrevendo os concursos de ingresso para as escolas públicas e o orgulho de pertencimento à Escola, a busca do Brasil para o sucesso de uma educação de qualidade.

No terceiro capítulo, Anos Antes, coloca o direito à educação, garantido pela Constituição brasileira. No quarto capítulo, Contextualizando, faz uma análise cuidadosa do período das ocupações, salientando, segundo a opinião dos envolvidos, que a reorganização das escolas propostas pela Secretaria da Educação não foi a de que houvesse um fomento de melhora nas escolas, mas os resultados foram desencadeadores de uma série de consequências negativas para os estudantes, para todos integrantes da Educação Estadual, para pais e para a sociedade em geral.

No quinto e último capítulo, Protagonismo Juvenil, a autora estabelece relações, no período, entre as diferentes ocupações nas escolas paulistas ressaltando, conforme intenção do livro, detalhes mais apurados sobre a Caetano de Campos.

Ao término de suas excelentes reflexões, a autora conclui que para aqueles que não 
compreenderam essa realidade e se mostraram contrários ao movimento, a defesa da pedagogia autônoma do aluno estava somente na ideologia. E de ideologia o universo estava repleto. Saímos da teoria, dos livros e dos artigos, logo houve protagonismo juvenil.

Marco Justo Losso, que também foi meu aluno no mesmo curso Lato Senso na PUC-SP, no mesmo grupo que Cyntia e, da mesma forma, foi aluno brilhante, inteligente e pesquisador. Pretendia ir para o Stricto Senso, o que lamento muito a sua desistência. A ele coube o epílogo desta obra, elaborado de forma criteriosa e inteligentemente escrito em um texto curto, mas substancioso.

Por ser um livro escrito por uma historiadora, com colaboração de sujeitos de áreas afins, podemos pensar a História e o papel do historiador ao utilizar a narrativa para produzir as mais diversas interpretações de um acontecimento, estabelecendo a recuperação dos cacos e dos ruídos polifônicos do passado, de modo a criar uma relação, nem sempre apaixonante, mas extremamente necessária. O historiador, ao buscar outras áreas de conhecimento que o seduzam, dialoga com elas. Contudo, não abandona o elemento documental, mesmo ao se afastar momentaneamente da História, o que nos permite observar que há sempre, parafraseando Mircea Eliade, "um eterno retorno à História".

Esta obra trata de um estudo histórico que se encaixa no interdisciplinar, onde o olhar atento da pesquisadora experiente cruzou as fontes orais e os registros da legislação educacional em um diálogo com a historiografia.

Registrando sujeitos adultos e adolescentes na multiplicidade das suas tarefas e sonhos, na construção dos espaços e nas diversas temporalidades valoriza as lembranças nas marcas que a História deixou ao longo do seu processo de forma didática e competente.

Parabenizo Cyntia pela arrojada obra que, tenho certeza, será muito apreciada por todos que tiverem a oportunidade de lê-la. 
